УДК 930.2:378.011.3-051

DOI https://doi.org/10.31470/2518-7732-2019-1(15)-83-89

\title{
Єрічева Тамара,
}

Ericheva Tamara,

старший викладач кафедри медико-біологічних Senior Lecturer Department Medical and дисциплін і валеології, tamara.ericheva@gmail.com https://orcid.org/0000-0003-0334-1073 Державний вищий навчальний заклад «Переяслав-Хмельницький державний педагогічний університет імені Григорія Сковороди», м. Переяслав-Хмельницький, вул. Сухомлинського, 30, Київська обл., Україна, 08401

\section{Палієнко Ольга,}

кандидат історичних наук, доцент кафедри медико-біологічних дисциплін і валеології, olgapalienko03@gmail.com https://orcid.org/0000-0002-1832-7154 Державний вищий навчальний заклад «Переяслав-Хмельницький державний педагогічний університет імені Григорія Сковороди», м. Переяслав-Хмельницький, вул. Сухомлинського, 30, Київська обл., Україна, 08401 Biological Disciplines andValeology, tamara.ericheva@gmail.com https://orcid.org/0000-0003-0334-1073 Pereiaslav-Khmelnytskyi Hryhorii Skovoroda State Pedagogical University, 30, Sukhomlynsky Str., Pereiaslav-Khmelnytskyi, Kyiv region, Ukraine, 08401

\section{Історіографія проблеми підготовки майбутніх учителів до організації проектної діяльності}

Метою статті є дослідження історії впровадження методу проектів у школах України, виявлення недоліків і досягнень із метою удосконалення підготовки майбутніх учителів до організаиї проектного навчання.

Методологія дослідження трунтується на принципах історизму, об'єктивності та системного аналізу фактів і подій.

У статті розглянуто актуальність проблеми підготовки майбутніх учителів до організації проектної діяльності. Спираючись на роботи вчених проаналізовано проектне навчання на Украйні в історичному аспекті.

Результати дослідження дали можливість виявити, щзо першим періодом активного використання методу проектів в Україні можна назвати 20-30 роки минулого століття. Проте, з ряду причин, експеримент зазнав поразки.

На другому етапі (1931-2000рр.) вказаній проблемі не приділялося належної уваги. Починаючи з 1931 року на сторінках радянської літератури розпочалась критика методу проектів.

У радянський період педагогіка ставила перед иколою завдання підготувати учнів, використовуючи в основному пояснювально-ілюстративні технології.

Лише з 2001 року (третій період) проектне навчання почало набувати популярності. Кризові явища у всіх галузях суспільного життя, включаючи сферу освіти, призвели до заміни авторитарної парадигми навчання на особистісно-орієнтовану.

З'являються публікачії українських вчених, педагогів і викладачів про вплив методу проектів на освітній процес, вивчається сутність проектної діяльності учнів.

Проектна технологія навчання починає вивчаться разом із іншими інновачійними технологіями. та набуває популярності при вивченні багатьох шкільних предметів.

Проводяться дослідження використання методу проектів у позакласній діяльності класного керівника.

Проте, недостатньо вивчається питання підготовки майбутніх учителів до організації проектної діяльності учнів.

Проведений аналіз історичних фактів дає можливість зробити висновок, щзо неналежна підготовка педагогічних кадрів, відсутність методичного комплексу підготовки призводить до негативних наслідків. Дуже важливо, щзоб будучи студентами, майбутні учителі вже були підготовлені до організації проектної діяльності.

Ключові слова: метод проектів, проектне навчання в Україні, період історії, підготовка майбутніх учителів, підходи до навчання. 


\section{Historiography of the problem of future teachers training for the organization of project-based activities}

The aim of the study is to explore the history of applying the project method in Ukrainian schools, to expose shortcomings and achievements in order to improve the future teachers training for the organization of project-based learning.

The methodology of research is based on the principles of historicity, objectivity and system analysis of facts and events.

The article considers the significance of the issue of future teachers training for the organization of project-based activities. Based on the work of scientists, project-based learning in Ukraine was analyzed in the historical aspect.

The results of the study make it possible to reveal that the first period of active applying of the project method in Ukraine can be called the 20s-30s of the past century. However, for various reasons, the experiment wasn't successful.

At the second stage (1931-2000), special attention has not been paid to the issue. The criticism of the projects method has begun on the pages of Soviet literature since 1931.

In the Soviet period, pedagogy put the task for the school to prepare students, using mainly explanatory and illustrative technologies.

Only since 2001 (the third period) project-based learning has begun to gain popularity. Crisis phenomena in all spheres of public life, including education, have led to the replacement of the authoritarian paradigm of teaching with a person-oriented one.

During this period, there are publications of Ukrainian scientists, pedagogues and teachers about the effect of the projects method on the learning process, and the essence of students' project-based activities is studied.

The project-based learning technology is beginning to be studied along with other innovative technologies and is gaining popularity in the study of many school subjects.

The studies are being conducted on the applying of the project method in the extracurricular activities of the class teacher.

However, the issue of future teachers training for the organization of students' project-based activities is not sufficiently studied.

The analysis of historical facts makes it possible to conclude that inadequate training of pedagogical staff and the lack of a methodical complex in their training lead to negative results. Therefore, it is very important in order to students, future teachers have already been prepared for the organization of project-based activities.

Key words: project method, project-based learning in Ukraine, history period, future teachers training, approaches to learning.

Науковці визначають, що людство на початку ХХ ст. вступило до науково-технологічного етапу розвитку, характерними рисами якого є упровадження наукомістких, високих технологій; збільшення обсягу інформації, яку використовують люди; пріоритет способу виробництва над його результатом. Як наслідок інтенсивного розвитку сучасного суспільства - потреба в активних, діяльних людях, які могли б швидко пристосуватися до мінливих трудових умов, виконувати роботу з оптимальними енерговитратами. Соціальні умови суспільства потребують самостійних працівників, які можуть критично мислити, мають творчий підхід до праці, вміють працювати $з$ інформацією тощо. Виховання такої особистості можна найбільш ефективно реалізувати через проектну методику навчання. Вона є найбільш придатною для повноцінного розвитку особистості, підготовки ï до майбутньої трудової діяльності, оскільки дозволяє спрямувати навчання на особистість, пї потреби та інтереси.

Значною мірою теоретичні основи проектної діяльності розроблені у працях В. В. Гузєєва, О. М. Коберника, П. С. Лернера, Н. В. Матяш, Н. Ю. Пахомової, Дж. Пітта, Є. С. Полат, І. С. Сергєєва, В. К. Сидоренка, В. Д. Симоненка, І. Д. Чечеля, С. М. Ящука.

Значний внесок у розвиток проектного методу навчання зробили вітчизняні вчені П. П. Блонський, В. В. Ігнатьєва, Е. Г. Каганова, Н. К. Крупська, М. М. Пистрак, С. Т. Шацький, В. Н. Шульгін та зарубіжні педагоги і психологи Д. Дьюї, У. Х. Кілпатрик, Е. Колінгс.

Водночас, в історичному аспекті дана проблема майже не досліджувалася.

Теорія і практика проектної діяльності і проектного навчання почала активно розвиватися у кінці XIX - на початку XX століть, коли педагоги, філософи були націлені на те, щоб знайти способи, шляхи розвитку активного самостійного мислення дітей, щоб навчити їх не просто запам' ятовувати та відтворювати знання, які дає їм школа, а вміти використовувати їх на практиці [17]. Запровадженню проектної методики посприяв перехід від «школи пам’яті» до «школи мислення».

Професор педагогічного коледжу У. Кілпатрик у 1918 р. пише роботу «Метод проектів», в якій розглядає систему цільових актів педагогічного процесу. Основна ідея цього педагога 
будувалася на активній діяльності учнів у соціальному оточенні. Він був противником традиційного шкільного навчання, вважаючи, що воно негативно впливає на життя та характер дитини.

У. Кілпатрик дав таку характеристику методу проектів: «Це - метод планування доцільної (цілеспрямованої) діяльності у зв'язку з розв'язанням будь-якого навчально-шкільного завдання в реальній життєвій ситуації». [13, с. 8].

Запропонований У. Кілпатриком «метод проектів» набув широкого розповсюдження не тільки в Америці, а й у багатьох країнах Західної Свропи.

Український учений-педагог Й. Зільберфарб вказував на потребу імпортування організаційного і технічного педагогічного досвіду з найрозвиненіших країн світу, зокрема США. Він вказував, що можна запозичити з американської освітньої системи навчання за системою практичних цільових життєвих завдань (метод проектів). Й. Зільберфарб, вказуючи на ідеологічні розбіжності у визначенні мети і завдань виховання, виділяв наукову орієнтацію як основну рису американської освіти, що зближує наші освітні системи [9, с. 51].

Першим періодом використання методу проектів у навчанні учнів на Україні, яка входила до складу Радянської Росії можна назвати 1920-1930 pр.

А. Алексюк, досліджуючи цей період історії, аналізував причини, за яких радянські учителі позитивно ставилися до методу проектів. Він дійшов висновку, що педагоги намагалися змістом проектів зробити суспільно корисні справи, залучивши учнів до будівництва соціалізму, їм здавалося, що метод проектів може стати важливим засобом поєднання набутих знань із розв'язанням практичних завдань і тим самим сприятиме розвиткові самостійності та творчої ініціативи учнів [1, с. 110].

У 20-ті роки учителів для шкіл готували державні університети, інститути народної освіти, педагогічні інститути, вищі педагогічні курси (педтехнікуми), короткострокові педагогічні курси, а у 1925-1930 pр. також було створено систему заочної педагогічної освіти (Всеукраїнський заочний інститут народної освіти в Харкові) [4, с. 333-334]. Та суспільство гостро відчувало їх нестачу (вчителі працювали у дві зміни з великим навантаженням), а також було мало учителів зі спеціальною освітою. Як показав перепис 15 грудня 1927 р., у школах України працювало 10,1 \% учителів з вищою освітою, 12,8 \% закінчили педтехнікуми, 56 \% - середні школи, 21,1 \% мали тільки нижчу освіту [6, с. 61].

Також, для повноти картини того часу, потрібно враховувати політичні обставини. Проявом надуманої теорії Сталіна про зростання класової боротьби в період будівництва соціалізму стало огульне звинувачення в опортунізмі багатьох освітян, а звідси - політика масових чисток серед

учителів. У той час збільшилася кількість випадків необгрунтованих переміщень і звільнень учителів з роботи. У деяких випадках школи закривалися, оскільки вчителів масово було звільнено, а замінити їх не було ким [6, с. 62].

Радянська влада розглядала народного учителя як свого помічника в реалізації плану культурних перетворень, як агітатора і пропагандиста, тому у навчальних планах усіх навчальних педагогічних закладів було передбачено вивчення історії соціалізму, політичної економії, Радянської Конституції та політграмоти освітньої політики Комуністичної партії. Однак методичної підготовки явно не вистачало.

Аналіз літератури свідчить, що в освітніх закладах майбутніх учителів не могли ефективно навчати організовувати метод проектів у школі з таких причин:

- теорія використання методу проектів тільки розроблялась і не було єдиних розумінь цього поняття у радянській педагогіці;

- не було розроблено методичних посібників, рекомендацій для навчання студентів методу проектів;

- від учителя очікували якості пропагандиста комуністичних ідей й найменше - дослідника педагогічних інновацій.

Н. Крупська зазначала, що сама установка - перевести усю педагогічну працю на метод проектів - помилкова. Метод проектів, який було задумано як поєднання теорії з практикою внаслідок ігнорування сил та рівня розвитку дитини перетворився на підміну теоретичних знань вузьким практицизмом [10, с. 274].

Н. Крупська правильно розуміла, що перш за все потрібно визначити мету, цільову установку кожного проекту. Ця цільова установка має бути педагогічно обміркована, потім мають бути обумовлені засоби, цілі та можливості його виконання [10, с. 377]. 
А. Алексюк, аналізуючи комплексно-проектні програми 1930/31 навчального року, зробив висновок: «Метод проектів заміняв навчальні плани і програми, принижував роль учителя, замість озброєння учнів систематичними знаннями основ наук сприяв нагромадженню поверхових і невпорядкованих відомостей з навколишнього життя» [1, с. 111].

Прихильники методу проектів (М. Крупеніна, В. Шульгін, П. Блонський, Б. Ігнатьєв, Б. Манжос та інші) оголосили його єдиним засобом перетворення школи навчання на школу життя. Універсалізація методу проектів призвела до складання й видання комплексно-проектних програм для шкіл. Згодом його назвуть невдалим експериментом. Взагалі цей період в історії радянської школи розглядається як безперервне експериментування. Тоді розроблялися теоретично і застосовувалися на практиці навчання найновіші системи, форми і методи, створені передовою європейською і американською педагогічною думкою. Це були: комплексна система навчання, бригадно-лабораторний метод і метод проектів. Доля всіх цих педагогічних знахідок була однаковою. 5 вересня було видано постанову ЦК ВКП(б) про школу, у ній було засуджено «антиленінську теорію відмирання школи», під якою розуміли також метод проектів. Його з того часу називають «легковажне методичне прожектерство» [11].

Однак при всій абсурдності наслідків цих експериментів варто зазначити, що названі нові форми й методи навчання широко застосовувалися в радянській школі. Тому такий експеримент дає право робити висновки про педагогічну цінність цих форм і методів.

Відомий український педагог Г. Ващенко прагнув проаналізувати і з’ясувати причини провалу експерименту. Він зробив такі висновки:

1. Застосування методів навчання, що мають на меті розвинути особисту ініціативу учня $\mathrm{i}$ дух вільних творчих шукань, неможливе в країнах з тоталітарним режимом.

2. Не можна проектний метод навчання перетворювати в систему, що включає в себе всі інші форми й методи навчання. Проект є одним із методів навчальної роботи.

3. Школа ні за яких умов державного й політичного життя не може бути придатком до якогось виробництва. Вона мусить бути пов'язана з навколишнім життям і водночас залишатися закладом, що має своїм завданням всебічне виховання молодого покоління.

4. Ув'язуючи теорію з практикою, треба у процесі навчання уникати однобокого практицизму й головну увагу звертати на вироблення в учнів наукового світогляду й грунтовних знань i розвиток здібностей до логічного мислення. Це, між іншим, забезпечується різноманітністю методів, що їх застосовує школа в процесі навчання.

5. Не слід перевантажувати дітей практичними роботами, а особливо не треба давати їм практичних завдань, що не відповідають їхньому вікові або мають характер «чорнової роботи», що вимагає лише фізичних зусиль, а нічого не дає для розумового розвитку дитини [7, с. 14].

Аналізуючи вітчизняну педагогічну науку з 1920-1930 років, можна відзначити помітні досягнення. Цьому сприяли такі причини:

1. Позитивне ставлення керівників Наркомпросу до нововведень, залучення до співпраці великих та оригінально мислячих педагогів.

2. Ще працювали вчені - носії найкращих педагогічних традицій дореволюційної пори (С. Шацький).

3. Збереглися зв'язки з педагогічним світом.

Як ми бачимо, впровадження у навчальному 1930/1931 році комплексно-проектних програм мало багато недоліків, і найголовніший із них непідготовленість учителів, бо вищі навчальні заклади не мали ефективної системи підготовки учителів до методу проектів. Як свідчить аналіз літератури, здебільшого студенти мали поверхові суперечливі теоретичні поняття, i для педагогічної роботи за методом проектів не були готові.

Розвиток (1931-2001 рр.) На сторінках радянської літератури у цей період розпочалася критика методу проектів.

У підручнику за редакцією М. Гриценка засуджується метод проектів, який застосовували американські педагоги. Він трактується радянськими вченими як метод використання практичного досвіду дітей, що має великий недолік - недооцінку ролі школи і систематичних знань [4, с. 107].

У підручнику за редакцією Н. Константінова вважається недоліком зниження ролі учителя, де він виступає організатором, консультантом, але не керівником процесу навчання. Метод проектів розглядається як загроза класно-урочної системи навчання [5, с. 124-127].

Такі терміни, як «користь», «успіх», «бізнес», були далекі від ідеології радянського устрою, тому досягнення американських, європейських педагогів в розробці проектного навчання мали негативний відгук. 
Після засудження методу проектів радянські педагоги продовжують досліджувати проблеми самостійності та активізації пізнавальної діяльності учнів, але при цьому відмовляються від застосування проектного методу навчання у школі. Авторитарний устрій країни виражався у авторитарному стилі спілкування учителя з учнями. Учні виступають як об'єкти управління, виконавці планів учителя, тому самостійність учнів має певну межу. Без зміни парадигми освіти неможливо досягти певних поліпшень підготовки учня до життя.

Із 1931 по 1990 роки радянські педагоги виступають за більш широке застосування самостійної роботи учнів на уроці (Б. Ссипов, П. Підкасистий), тоді порушуються та переважно досить обгрунтовано вирішуються питання структури пізнавальної діяльності школяра розкриваються іiі внутрішні процеси (Г. Щукіна), вивчається проблема виховання потреби в знаннях у школярів (В. Ільїн) [3].

У радянський період педагогіка ставила перед школою завдання підготувати учнів, використовуючи в основному пояснювально-ілюстративні технології. Найбільш негативним фактором в цих технологіях $є$ виконання учнями навчальних дій та операцій в примусовому режимі, що не може не мати серйозних психологічних наслідків для всіх учасників освітнього процесу. Спроби активізувати пізнавальну діяльність учнів, використовуючи проблемне навчання, пошукові методи навчання, не могли вплинути на характер навчання, бо, вони були затиснені у рамки «авторитарної» парадигми освіти.

Наприкінці 80-х років, у період пошуку нових форм і методів навчання та загального захоплення «нестандартними уроками» у Радянському Союзі відлуння проектної системи можна помітити в технології колективних вправ, привнесеній з методики виховної роботи (комунарська методика І.Іванова). І. Іванов визначив поняття «захист фантастичних проектів» як пізнавальне діло-огляд, під час якого кожна група (бригада) учасників демонструє підготовлений нею проект, що втілює уявлення автора про один бік життя у майбутньому, і відповідає на запитання інших учасників, при цьому намагається переконливо обгрунтувати свої пропозиції. [3].

Запровадження проектного навчання в Україні (з 2001 р.) Соціально-економічні зміни у країнах колишнього Радянського Союзу, які пояснюються наявністю кризових явищ у всіх галузях суспільного життя, включаючи сферу освіти, призвели до заміни авторитарної парадигми навчання на особистісно-орієнтовану і в Україні.

Проектна технологія навчання починає вивчаться разом із іншими інноваційними технологіями: вальдорфська педагогіка, методика Монтессорі, технологія колективного творчого виховання тощо.

Починаючи з 2001 року в Україні визнається третій етап використання методу проектів у вітчизняних школах. У цьому році вийшли шкільні програми «Трудове навчання. 5-9 класи», де проектній діяльності учнів приділяється багато уваги [2]. 3'являються публікації українських вчених, педагогів і викладачів про вплив методу проектів на освітній процес, вивчається сутність проектної діяльності учнів.

У 2001 році у періодичному виданні «Трудова підготовка в закладах освіти» друкується стаття О. Коберника «Проектування на уроках трудового навчання» [7], це була перша спроба донести до учителів трудового навчання сутність понять «проект», «метод проектів», визначення типів проектів.

Починаючи з 2002 року друкуються статті С. Ящука, Л. Хоменко та інших із методичними порадами щодо проведення окремих тем трудового навчання.

О. Коберник, В. Бербец, В. Сидоренко, С. Ящук розробили методику навчання учнів 5-9 класів проектуванню в процесі вивчення технології обробки деревини і металу [8]. Багато з цих авторів підкреслюють, що використання методу проектів у шкільній практиці дає можливість: активізувати пізнавальну діяльність учнів; формувати у школярів специфічні вміння та навички загальнонаукового і комунікативного характеру.

Із 2003 року проектне навчання в Україні набуває популярності з багатьох шкільних предметах: історія, іноземна мова, література.

У початковій школі педагоги-новатори розробляють творчі проекти з урахуванням вікових особливостей учнів: В. Шутяк. Н. Котелянець зазначає, що молодші школярі виконуючи проекти вперше стикаються з завданням, в яких відсутнє єдине правильне рішення, тому проектна діяльність сприяє розвитку творчих рис особистості [4].

Проводяться дослідження використання методу проектів у позакласній діяльності класного керівника. Однією з найбільш відомих форм початкової проектної діяльності в школі стає конкурс проектів [14, с. 93]. 
Проте, недостатньо вивчається питання підготовки майбутніх учителів до організації проектної діяльності учнів. Тільки деякі навчальні заклади (переважно гімназії), переймаючись інноваційними ідеями у освіті, досліджували можливості підготувати педагогічний колектив закладу до організації проектної діяльності учнів.

Отже, на першому етапі - становленні проектної діяльності учнів у школах України 19231931 pр., підготовкою майбутнього вчителя до використання методу проектів практично не займались, на другому етапі - впровадження проектної діяльності учнів у шкільних програмах із трудового навчання 2001року, підготовці майбутнього вчителя до організації проектної діяльності не приділяється багато уваги, оскільки зміни у підходах до навчання відбуваються щодо вимог шкільних програм, а не щодо програм ВНЗ.

Дуже важливо, щоб будучи студентами, майбутні учителі вже були підготовлені до організації проектної діяльності учнів. Як свідчить історіографія цього питання, недоліки у підготовці педагогічних кадрів, відсутність методичного комплексу підготовки до застосування методу проектів призводять до негативних наслідків.

\section{ДЖЕРЕЛА ТА ЛІТЕРАТУРА}

1. Алексюк А. М. Загальні методи навчання в школі. Київ: Радянська школа, 1973. 264 с.

2. Денисенко Л., Левченко Г. Про нові експериментальні програми з трудового навчання для 5 - 9 класів // Трудова підготовка в закладах освіти. 2001. № 2. С. 44-45.

3. Ильин В. С. Проблемы воспитания потребности в знании у школьников. Ростов-на-Дону: Ростовское книжное издательство, 1971. 222 с.

4. Історія педагогіки: навч. посіб. / М. С. Грищенко та ін. Київ: Вища школа, 1973. 448 с.

5. Кліцаков І. О. Підготовка і виховання учительських кадрів на Україні (1927-1937 рр.) // Укр. іст. журн. 1990. № 2. С. 57-69.

6. Коберник О. Проектування на уроках трудового навчання // Трудова підготовка в закладах освіти. 2001. № 4. С. 12-14.

7. Коваленко В. Вплив ідей Д. Дьюї на українську школу й педагогіку 1920-1930 років // Шлях освіти. 1997. № 4. С. 51-55.

8. Методика навчання учнів 5-9 класів проектуванню в процесі вивчення технології обробки деревини і металу: навч.-метод. посіб. / О. Коберник, В. Бербец, В. Сидоренко, С. Ящук. Умань: УДПУ, 2004. 114 с.

9. Константинов Н. А., Медынский Е. Н., Шабаева М. Ф. История педагогики: учебн. для студ. пед. ин-тов. Москва.: Просвещение, 1982. 447 с.

10. Крупская Н. Педагогические сочинения: [в 6-ти томах]. Под ред. А. М. Арсеньева. Т. 4. Москва: Педагогика. 1979. 480 с.

11. Медынский Е. Н. История педагогики. Москва: Госуд. учебно-педагогическое издательство Министерства просвещения РСФСР. 1947. 578 с.

12. Тюрберт С. Метод проектов. Теоретические предпосылки и практика. Москва: МИР, 1925. $88 \mathrm{c}$.

13. Чуча Л. Г. Використання методу проектів в позакласній діяльності класного керівника // Теорія і практика особистісно-орієнтованої освіти: матеріали Всеук. наук.-практ. конференції 8-10 квітня 2003 р. Ч. 2. Київ - Запоріжжя: Просвіта, 2003. С. 90-94.

14. Ярошинский И. В. Опыт реализации проектов в английской школе // Школа и производство. 1996. № 1. С. 26-27.

\section{REFERENCES}

1. Aleksiuk, A. M. (1973). Zahalni metody navchannia $v$ shkoli [General methods of teaching at school]. Kyiv : Radianska shkola [in Ukrainian].

2. Denisenko, L., \& Levchenko G. (2001). Pro novi eksperymentalni prohramy z trudovoho navchannia dlia 5-9 klasiv [About new experimental programs on labor training for 5-9 classes]. Trudova pidhotovka v zakladakh osvity - Labor training in educational institutions. 2, 44-45 [in Ukrainian].

3. Ilyin, V. S. (1971). Problemy vospitaniya potrebnosti v znanii u shkol'nikov [Problems of upbringing the need for knowledge among schoolchildren]. Rostov-na-Donu: Rostovskoe knizhnoe izdatel'stvo [in Russian].

4. Grishchenko, M. S. (1973). Istoriia pedahohiky [History of pedagogy]. Kyiv: Vyshcha shkola [in Ukrainian]. 
5. Klitsakov, I. O. (1990). Pidhotovka i vykhovannia uchytelskykh kadriv na Ukraini (1927-1937 rr.) [Training and education of teaching staff in Ukraine (1927-1937)]. Ukrainskyi istorychnyi zhurnal - Ukrainskyi istorychnyi zhurnal. 2, 57-69 [in Ukrainian].

6. Kobernik, O. (2001). Proektuvannia na urokakh trudovoho navchannia [Designing in the lessons of labor education]. Trudova pidhotovka v zakladakh osvity-Labor training in educational institutions. 4, 14-45 [in Ukrainian].

7. Kovalenko, V. (1997). Vplyv idei D. Diui na ukrainsku shkolu y pedahohiku 1920-1930 rokiv [Influence of D. Dewey's ideas on the Ukrainian school and pedagogy of 1920-1930]. Shliakh osvity - Shliakh's sensibility. 4, 51-55 [in Ukrainian].

8. Kobernik, O., Berbets, V., Sidorenko, V., \& Yaschuk, S. (2004). Metodyka navchannia uchniv 5 - 9 klasiv proektuvanniu $v$ protsesi vyvchennia tekhnolohii obrobky derevyny i metalu [Methods of teaching students of grades 5-9 for designing in the process of studying technology of wood and metal processing]. Uman: UDPU [in Ukrainian].

9. Konstantinov, N. A., Medynsky, E. N., \& Shabaeva, M. F. (1982). Istoriya pedagogiki [The history of pedagogy]. Moscow: Prosveshchenie [in Russian].

10. Krupskaya, N. (1979). Pedagogicheskie sochineniya [Pedagogical writings]. (Vols. 1-6). A. M. Arsenyev (Ed.). Moscow: Pedagogika [in Russian].

11. Medynsky, E. N. (1947). Istoriya pedagogiki [The history of pedagogy]. Moscow: Gosud. uchebno-pedagogicheskoe izdatel'stvo Ministerstva prosveshcheniya [in Russian].

12. Turbert, S. (1925). Metod proektov. Teoreticheskie predposylki i praktika [Method projects. Theoretical background and practice]. Moscow: MIR [in Russian].

13. Chucha, L. G. (2003). Vykorystannia metodu proektiv v pozaklasnii diialnosti klasnoho kerivnyka [Use of the method of projects in the extracurricular activities of a class teacher]. Teoriia i praktyka osobystisno-oriientovanoi osvity: materialy Vseukrainskoi naukovopraktysnoi konferentsii 8-10 kvitnia 2003 r. [Theory and Practice of Personality-Oriented Education: Materials of the All-Ukrainian Scientific and Practical Conference April 8-10, 2003 ]. (Vols. 2), (pp. 90-94). Kyiv - Zaporizhzhya: Prosvita [in Ukrainian].

14. Yaroshinsky, I. V. (1991). Opyt realizatsii proektov v angliyskoy shkole [Experience of project implementation in the English school]. Shkola y proyzvodstvo - School and production. 1, 26-27 [in Russian].

Одержано 12.04.2019. 